\title{
Severe sepsis caused by serious gastrointestinal infection in SJIA patients treated with IL-6 receptor antagonist: a case report
}

\author{
Meng $\mathrm{Xu}^{\dagger}$, Congcong Liư ${ }^{\dagger}$ Lishuang Guo and Sirui Yang ${ }^{*}$
}

\begin{abstract}
Background: Interleukin (IL)-6 plays an essential role in the pathogenesis of systemic juvenile idiopathic arthritis (sJIA). Tocilizumab (TCZ), a kind of biological agent against both membrane and soluble IL-6 receptor, is the only biological agent approved for the treatment of sJIA in China. Infections are the most common adverse events during TCZ therapy, and most of infections are mild or moderate. Severe sepsis originated from gastrointestinal infection is rarely reported.

Case presentation: In this article, we reported two 13-year-old sJIA patients who suffered from life-threatening infections after TCZ administration. Within one day, both of them presented rapidly progressive conditions that included fever, abdominal pain, dizziness, diarrhea and vomiting, and laboratory tests showed multi-organ dysfunctions. They were diagnosed with severe sepsis and septic shock that were supposed to be caused by the pathogens from the gastrointestinal tract, and they were eventually rescued by timely treatment. In addition, we also reviewed the literature about serious gastrointestinal infections and sepsis in sJIA patients receiving TCZ therapy.

Conclusions: In summary, for sJIA patients with TCZ therapy, invading pathogens from the gastrointestinal tract can cause an intensely systemic infection that may even be fatal. Therefore, it is essential to pay attention to the gastrointestinal management of sJIA patients as well as remind them of their intestinal hygiene.
\end{abstract}

Keywords: Systemic juvenile idiopathic arthritis, Tocilizumab, Gastrointestinal infection, Sepsis, Case report

\section{Background}

Systemic juvenile idiopathic arthritis (sJIA) is an autoinflammatory disease characterized by high spiking fever, evanescent skin rash, arthritis, and remarkable overexpression of pro-inflammatory cytokines, such as interleukin (IL)-1, IL-6, and tumor growth factor-alpha (TNF- $\alpha$ ) [1]. Biological agents that target these cytokines or their

\footnotetext{
* Correspondence: sryang@jlu.edu.cn

${ }^{+}$Meng Xu and Congcong Liu contributed equally to this work. Department of Pediatric Rheumatology, Immunology and Allergy, The First Hospital of Jilin University, Changchun 130021, China
}

receptors can efficiently delay the joint damage. Tocilizumab (TCZ) is an IL-6 receptor antagonist binding to both membrane-bound and soluble IL- 6 receptors; it is increasingly used for sJIA treatment in China. Notably, infections are the main adverse events [2], and may also be masked [3, 4]. sJIA patients treated with TCZ are susceptible to infections, especially respiratory and gastrointestinal (GI) [5]. However, severe sepsis caused by GI infections is rarely recorded. Herein, we reported two cases of sJIA patients who suffered from severe sepsis caused by GI infections and also reviewed the literature

(C) The Author(s). 2020 Open Access This article is licensed under a Creative Commons Attribution 4.0 International License, which permits use, sharing, adaptation, distribution and reproduction in any medium or format, as long as you give appropriate credit to the original author(s) and the source, provide a link to the Creative Commons licence, and indicate if changes were made. The images or other third party material in this article are included in the article's Creative Commons licence, unless indicated otherwise in a credit line to the material. If material is not included in the article's Creative Commons licence and your intended use is not permitted by statutory regulation or exceeds the permitted use, you will need to obtain permission directly from the copyright holder. To view a copy of this licence, visit http://creativecommons.org/licenses/by/4.0/ The Creative Commons Public Domain Dedication waiver (http://creativecommons.org/publicdomain/zero/1.0/) applies to the data made available in this article, unless otherwise stated in a credit line to the data. 
regarding sepsis and GI infections occurring in sJIA patients receiving TCZ therapy.

\section{Case presentation \\ Case 1}

A 13-year-old boy was admitted to our hospital in the fall of 2017, with the complaint of persistent fever, abdominal pain, dizziness, diarrhea, and vomiting for one day. During the past day, the temperature ranged from 38.6 to $40.2{ }^{\circ} \mathrm{C}$. Before disease onset, he ate some underdone pork. In contrast to his severe condition, his parents, who ate the same, just exhibited mild diarrhea. At admission, the patient presented signs of shock, including unconsciousness, weak pulse, irregular heart and respiratory rhythm, undetectable blood pressure, and prolonged capillary refilling time (CRT). Therefore, he was transferred to the pediatric intensive care unit (PICU). The white blood cell count (WBC) was $20.41 \times$ $10^{9} / \mathrm{L}$, and the value of C-reactive protein (CRP) was $107.13 \mathrm{mg} / \mathrm{L}$ (Table 1). Laboratory tests also indicated the dysfunction of the heart, liver, and kidney. Bedside $\mathrm{X}$-ray excluded the perforation and obstruction of the GI tract. The abdominal ultrasound found a few liquidlike intestinal contents. He was diagnosed with severe sepsis and septic shock; rescue strategies, including fluid resuscitation, vasopressor agents, and mechanical ventilation, were performed. Additionally, continuous renal replacement therapy and intravenous meropenem, methylprednisolone $(2 \mathrm{mg} / \mathrm{kg}$ twice per day), and intravenous immunoglobulins (IVIG, $400 \mathrm{mg} / \mathrm{kg}$ per day for three days) were administered because of the low level of IgG. On the third day of hospitalization, blood culture detected Salmonella enteritidis, which was sensitive to meropenem. Fourteen days after the admission, he was transferred to our department with a stable condition. Subsequently, TCZ was removed from the therapeutic plan.

Seventy-six months before the admission, the patient was diagnosed with sJIA in another hospital. Initially, he was treated with intravenous methylprednisolone, oral prednisone acetate, and methotrexate (MTX). However, shortly after each cessation of the oral prednisone acetate, the disease flared with the presence of fever, skin rash, and arthritis. Four months before this admission, the patient came to our department. Considering the poor treatment response of the patient to glucocorticoid, we stopped using glucocorticoid, and then we administered the first infusion of TCZ $(8 \mathrm{mg} / \mathrm{kg}$, every two weeks for the first two months and every three weeks subsequently) and oral MTX. The last infusion of TCZ was used 13 days before this admission. During the period of TCZ therapy, there were no signs of infection and neutropenia. The laboratory tests, including liver function, renal function, and levels of immunoglobulins before each administration of TCZ were normal.

\section{Case 2}

A 13-year-old boy was admitted to our department in the summer of 2018 due to persistent fever, abdominal pain, diarrhea, vomiting, and dizziness for one day after eating roast meat. During the past day, the minimum body temperature was $38.3^{\circ} \mathrm{C}$, and the maximum was $39.8^{\circ} \mathrm{C}$. Conversely, his family, who ate the same food, did not show any discomfort. At admission, he presented a poor condition with dysphoria, muffled heart sounds, increased heart and breath rate, low blood pressure, and prolonged CRT. Due to the unstable vital signs, he was transferred to PICU. Fluid resuscitation, vasopressor agents, and mechanical ventilation were performed immediately. The WBC was $38.76 \times 10^{9} / \mathrm{L}$, and the value of CRP was $95.9 \mathrm{mg} / \mathrm{L}$ (Table 1). Other laboratory tests showed multi-organ dysfunction. Bedside imaging examinations detected gas in the intestine. Also, he was diagnosed with severe sepsis and septic shock, and subsequently, meropenem, methylprednisolone $(2 \mathrm{mg} / \mathrm{kg}$ twice per day), and continuous renal replacement therapy were administered. Blood culture was negative. Eleven days after admission, with the improvement of the disease, he was transferred to our department. Then, TCZ was discontinued because of this severe event. He was diagnosed with sJIA 53 months before this admission, and 20 months ago, the treatment regimen was changed from oral prednisone acetate to intravenous TCZ. Eight months before this admission, he was diagnosed with influenza with the presence of neutropenia, which returned to normal after oral oseltamivir. Thirteen days before this admission, there were no signs of infection and neutropenia, and therefore, the last infusion of TCZ was given.

\section{Search strategy}

The literature review was conducted to identify clinical studies regarding the serious adverse events (SAEs) of TCZ treatment in sJIA patients. A search of PubMed, without limitation on dates, with a combination of "Tocilizumab" AND "systemic juvenile idiopathic arthritis," and with the restriction on the English language, and age for the child (birth to 18 years), was performed. Of the 65 searched articles, 21 review articles were excluded. The remaining 44 articles were reviewed; of these, 9 recorded the SAEs of TCZ therapy in sJIA patients. Information related to total SAEs, severe and GI infections and sepsis was collected.

\section{Results}

Table 1 shows the clinical and laboratory characteristics of both patients. Table 2 summarizes the SAEs recorded 
Table 1 Clinical and laboratory characteristics of the two patients

\begin{tabular}{|c|c|c|c|}
\hline & Case 1 & Case 2 & \\
\hline \multicolumn{4}{|l|}{ General characteristics } \\
\hline Age, years & 13 & 13 & \\
\hline Sex & Male & Male & \\
\hline Weight, kg & 40.7 & 54 & \\
\hline Dose of TCZ & $8 \mathrm{mg} / \mathrm{kg}$ & $8 \mathrm{mg} / \mathrm{kg}$ & \\
\hline Potential cause & Underdone pork & Roast meat & \\
\hline \multirow[t]{5}{*}{ Initial symptoms } & Fever & Fever & \\
\hline & Abdominal pain & Abdominal pain & \\
\hline & Dizziness & Dizziness & \\
\hline & Diarrhea & Diarrhea & \\
\hline & Vomiting & Vomiting & \\
\hline \multicolumn{4}{|l|}{ Signs } \\
\hline State & Unconsciousness & Dysphoria & \\
\hline $\mathrm{HR}, / \min$ & 141 & 174 & \\
\hline $\mathrm{RR}$, /min & 41 & 56 & \\
\hline $\mathrm{BP}, \mathrm{mmHg}$ & Undetectable & $80 / 42$ & \\
\hline MAP, mmHg & Undetectable ${ }^{a}$ & $56^{\mathrm{a}}$ & \\
\hline $\mathrm{SpO}_{2}, \%$ & 76 & 83 & \\
\hline CRT, second & 5 & $>5$ & \\
\hline Laboratory findings & & & Normal value \\
\hline WBC, $10^{9} / \mathrm{L}$ & 20.41 & 38.76 & $3.5-9.5$ \\
\hline Neutrophil, \% & 78 & 87 & $40-75$ \\
\hline Hemoglobin, g/L & 118 & 121 & $115-150$ \\
\hline Platelet, $10^{9} / \mathrm{L}$ & 458 & 399 & $125-350$ \\
\hline$C R P, m g / L$ & 107.13 & 95.9 & $0-3$ \\
\hline $\mathrm{PCT}, \mathrm{ng} / \mathrm{ml}$ & 15.86 & 37.19 & $0-0.5$ \\
\hline $\mathrm{ESR}, \mathrm{mm} / \mathrm{h}$ & 113 & 128 & $0-20$ \\
\hline Ferritin, $\mu \mathrm{g} / \mathrm{L}$ & $4118^{b}$ & $5560^{b}$ & $10-120$ \\
\hline Fibrinogen, g/L & $2.6^{b}$ & $3.01^{\mathrm{b}}$ & $1.8-4.0$ \\
\hline APTT, second & 61.7 & 31.2 & $21-33$ \\
\hline PT, second & 29 & 17.3 & $0-13$ \\
\hline AST, U/L & $71.4^{b}$ & $238.1^{b}$ & $13-35$ \\
\hline$A L T, U / L$ & 94.3 & 982.3 & $7-40$ \\
\hline BNP, pg/ml & 17,800 & 1230 & $0.1-1.0$ \\
\hline Creatinine, $\mu \mathrm{mol} / \mathrm{L}$ & $305.4^{\mathrm{a}}$ & $295.3^{\mathrm{a}}$ & $41-73$ \\
\hline Lactic acid, mmol/L & 5.3 & 4.7 & $0-125$ \\
\hline $\operatorname{lgG}, g / L$ & 3.98 & 6.8 & $8.6-17.4$ \\
\hline $\lg A, g / L$ & 0.54 & 0.63 & $1.0-4.2$ \\
\hline $\operatorname{lgM}, g / L$ & 0.32 & 1.3 & $0.5-2.8$ \\
\hline Blood culture & Salmonella enteritidis & Negative & Negative \\
\hline
\end{tabular}

$H R$ heart rate, $R R$ respiratory rate, $B P$ blood pressure, $M A P$ mean arterial pressure, $\mathrm{SpO}_{2}$ percutaneous blood oxygen saturation, $C R T$ capillary refilling time, WBC white blood cell counts, CRP C-reactive protein, $P C T$ procalcitonin, ESR erythrocyte sedimentation rate, APTT activated partial thromboplastin time, $P T$ prothrombin time, AST aspartate transaminase, ALT alanine transaminase, BNP brain natriuretic peptide, Ig immunoglobulin

a Terms included in the criteria of sepsis

${ }^{\mathrm{b}}$ Terms included in the criteria of MAS 
Table 2 Serious adverse events recorded by previous studies after TCZ infusion in SJIA patients

\begin{tabular}{|c|c|c|c|c|c|c|c|c|}
\hline $\begin{array}{l}\text { Authors and } \\
\text { references }\end{array}$ & Years & Study design & Duration & $\begin{array}{l}\text { No. of } \\
\text { patients }\end{array}$ & $\begin{array}{l}\text { SAEs } \\
\text { no. of } \\
\text { events }\end{array}$ & $\begin{array}{l}\text { Serious } \\
\text { infections } \\
\text { no. of events }\end{array}$ & $\begin{array}{l}\text { Serious Gl } \\
\text { infections } \\
\text { no. of events }\end{array}$ & $\begin{array}{l}\text { sepsis } \\
\text { no. of events }\end{array}$ \\
\hline Yokota et al. [6] & 2005 & OL, Phase II & 14 weeks & 11 & 0 & 0 & 0 & 0 \\
\hline Woo et al. [7] & 2005 & OL, Phase II & 4-8 weeks & 15 & 5 & 2 & 0 & 0 \\
\hline Yokota et al. [8] & 2008 & $\mathrm{R}, \mathrm{DB}, \mathrm{PC}$, Phase III & $\begin{array}{l}6 \text { weeks OL lead-in phase } \\
12 \text { weeks DB phase } \\
48 \text { weeks OL- extension } \\
\text { phase }\end{array}$ & 56 & 15 & Unknown $^{b}$ & Unknown $^{\mathrm{b}}$ & 0 \\
\hline De Benedetti et al. [2] & 2012 & R, DB, PC, Phase III & $\begin{array}{l}12 \text { weeks DB phase } \\
96 \text { weeks OL extension } \\
\text { phase }\end{array}$ & 112 & 39 & 18 & 5 & 1 \\
\hline Yokota et al. [9] & 2014 & $\begin{array}{l}\text { Long-term extension } \\
\text { study of their } 2 \\
\text { previous studies }\end{array}$ & 168 weeks & 67 & 78 & 30 & 13 & 0 \\
\hline Yokota et al. [10] & 2016 & Post marketing surveillance & 52 weeks & 417 & 222 & 74 & 9 & 3 \\
\hline Horneff et al. [11] & 2017 & Retrospective study & $2000-2015$ & $71^{a}$ & 14 & 2 & 0 & 0 \\
\hline Kimura et al. [12] & 2017 & Pilot study & 9 months & $10^{\mathrm{a}}$ & 1 & 0 & 0 & 0 \\
\hline Bielak et al. [13] & 2018 & Retrospective study & 7/2009-4/2014 & 46 & 2 & 0 & 0 & 0 \\
\hline
\end{tabular}

$O L$ open-label, $R$ randomized, $D B$ double blind, $P C$ placebo-controlled, SAEs serious adverse events, GI gastrointestinal

a number of patients involved in the sJlA group of the study

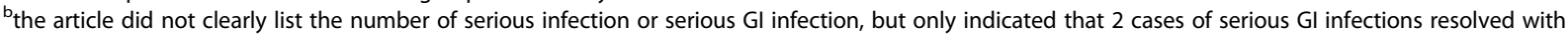
antibiotic treatment

by previous studies after TCZ infusion in sJIA patients [2, 6-13]. 6/9 articles recorded severe infectious events and four observed severe GI infections. In addition, two articles documented four septic events in SIIA patients receiving $\mathrm{TCZ}$.

\section{Discussion and conclusion}

The two patients presented extremely similar clinical and laboratory manifestations, including fever, abdominal pain, diarrhea, vomiting, dizziness, high level of inflammatory indicators, and multi-organ dysfunctions. In addition, the vital signs were unstable at the time of admission. According to the criteria of "sepsis-3," they were diagnosed with severe sepsis and septic shock [14]. In a randomized, double-blind, placebo-controlled Phase III trial that was conducted by De Benedetti et al. [2], one patient was diagnosed with sepsis and died on the same day. Postmortem blood and stool cultures yielded Streptococcus. The other three septic events were recorded by Yokota et al. [10] in 2015, and 1/3 patients died due to Pseudomonas infection. In the current two patients, given the history of eating unclean food and their obvious GI symptoms, we speculated that the severe illnesses were caused by GI pathogens. These GI infections are a cause of sepsis and could be fatal if the patients are not treated promptly. Also, the two patients presented remarkably similar clinical features and both developed infectious symptoms on the 13th day after TCZ administration. A correlation between the onset of severe infections and the pharmacokinetics of TCZ is yet to be elucidated. Before the two serious events, GI infection was neglected; however, now, we speculated that TCZ therapy should be recommended to sJIA patients with caution before their dietary hygiene is essential.

Given the immunosuppressive action of TCZ, we speculated that such serious illnesses resulting from GI infections were related to the blockade of IL- 6 signal. The exact mechanism of TCZ related to GI infection is yet unknown. A recent study found that sJIA patients presented intestinal microbiota dysbiosis, which was partially restored in inactive patients [15]. The changes in the composition of intestinal microbiota might increase intestinal permeability [16]. Hence, the aberrant intestinal microbiota may be a cause of GI infections in the patients. Supposedly, IL- 6 regulates the barrier function of GI mucous. A previous mouse-model study found that the administration of IL- 6 increases intestinal hyperplasia and improves the barrier function of the small bowel. Conversely, IL-6-null mice show increased injury of the intestinal cell [17]. Thus, we speculated that inhibition of the IL- 6 signal by TCZ facilitates the invasion of infectious agents through the GI tract.

Macrophage activation syndrome (MAS) is another life-threatening complication during sJIA and can be characterized by sustained fever, hyperferritinemia, cytopenia, coagulopathy, and multi-organ dysfunctions [18, 19], which are part of the features of sepsis [20]. Interestingly, clinical and laboratory features of our patients suggested MAS, including persistent fever, elevated levels of ferritin and AST, and decreased fibrinogen [21]. 
Since the main principle of therapy is different $[22,23]$, the differential diagnosis between MAS and sepsis is required, but may be difficult. However, the decrease in the number of white blood cells and platelets is the early event of MAS and often occurs before the deterioration of the patients' conditions. Although some of the clinical features of MAS may be masked by the application of TCZ [24], leukocytopenia and thrombocytopenia are commonly observed in MAS rather than sepsis [25, 26]. In addition, MAS commonly results in the dysfunction of the central nervous system, heart, lung, and kidney, while rarely causing abdominal symptoms [27]. Based on the above considerations, the patients were diagnosed with sepsis. However, the way of differential diagnosis between sepsis and MAS could not be addressed in this case study, and more rigorous studies are needed.

In summary, invading pathogens from GI tract can lead to severe sepsis and may even be fatal if the patient is not timely treated. Therefore, clinicians should pay enough attention to gastrointestinal infections of sJIA patients who are receiving TCZ therapy. It is necessary to remind the patients to keep a clean and healthy diet.

\section{Abbreviations}

CRT: Capillary refilling time; GI: Gastrointestinal; IVIG: Intravenous immunoglobulin; MAS: Macrophage activation syndrome; PICU: Pediatric intensive care unit; SAEs: Serious adverse events; sJIA: systemic-onset juvenile idiopathic arthritis; TCZ: Tocilizumab

\section{Acknowledgments}

The authors thank the patients for their participation in this study.

\section{Authors' contributions}

$\mathrm{MX}$ and $\mathrm{CL}$ were major contributors in analyzing and interpreting the data, and in writing manuscript. LG and MX interpreted the data and discussed the results, which are vital for formation of conception. SY contributed to the conception and design of the study and preparing and revising the manuscript. All authors have read and approved the final manuscript.

\section{Funding}

None.

\section{Availability of data and materials}

Not applicable.

\section{Ethics approval and consent to participate}

The experimental protocols were established following the Declaration of Helsinki and approved by the Human Ethics Committee of Jilin University (Changchun, China). Written informed consent was obtained from all children's parents.

\section{Consent for publication}

Written informed consent for publication of their clinical details was obtained from their parents.

\section{Competing interests}

The authors declare that they have no competing interests.

Received: 22 December 2019 Accepted: 12 March 2020 Published online: 18 March 2020

\section{References}

1. Mellins E, Macaubas C, Grom A. Pathogenesis of systemic juvenile idiopathic arthritis: some answers, more questions. Nat Rev Rheumatol. 2011;7(7):416-26.
2. De Benedetti F, Brunner HI, Ruperto N, Kenwright A, Wright S, Calvo I, Cuttica R, Ravelli A, Schneider R, Woo P, et al. Randomized trial of tocilizumab in systemic juvenile idiopathic arthritis. N Engl J Med. 2012; 367(25):2385-95.

3. Dumaine C, Bekkar S, Belot A, Cabrera N, Malik S, von Scheven A, Carbasse A, Woerner A, Wouters C, Bouayed K, et al. Infectious adverse events in children with juvenile idiopathic arthritis treated with biological agents in a real-life setting: data from the JIRcohorte. Joint Bone Spine. 2020;87(1):49-55.

4. Berger CT, Rebholz-Chaves B, Recher M, Manigold T, Daikeler T. Serial IL-6 measurements in patients with tocilizumab-treated large-vessel vasculitis detect infections and may predict early relapses. Ann Rheum Dis. 2019;78(7): 1012-4.

5. Machado SH, Xavier RM. Safety of tocilizumab in the treatment of juvenile idiopathic arthritis. Expert Opin Drug Saf. 2017;16(4):493-500.

6. Yokota S, Miyamae T, Imagawa T, Iwata N, Katakura S, Mori M, Woo P, Nishimoto N, Yoshizaki K, Kishimoto T. Therapeutic efficacy of humanized recombinant anti-interleukin-6 receptor antibody in children with systemiconset juvenile idiopathic arthritis. Arthritis Rheum. 2005;52(3):818-25.

7. Woo P, Wilkinson N, Prieur AM, Southwood T, Leone V, Livermore P, Wythe $H$, Thomson D, Kishimoto T. Open label phase II trial of single, ascending doses of MRA in Caucasian children with severe systemic juvenile idiopathic arthritis: proof of principle of the efficacy of $\mathrm{IL}-6$ receptor blockade in this type of arthritis and demonstration of prolonged clinical improvement. Arthritis Res Ther. 2005;7(6):R1281-8.

8. Yokota S, Imagawa T, Mori M, Miyamae T, Aihara Y, Takei S, Iwata N, Umebayashi H, Murata T, Miyoshi M, et al. Efficacy and safety of tocilizumab in patients with systemic-onset juvenile idiopathic arthritis: a randomised, double-blind, placebo-controlled, withdrawal phase III trial. Lancet. 2008; 371(9617):998-1006.

9. Yokota S, Imagawa T, Mori M, Miyamae T, Takei S, Iwata N, Umebayashi H, Murata T, Miyoshi M, Tomiita M, et al. Longterm safety and effectiveness of the anti-interleukin 6 receptor monoclonal antibody tocilizumab in patients with systemic juvenile idiopathic arthritis in Japan. J Rheumatol. 2014;41(4):759-67.

10. Yokota S, Itoh Y, Morio T, Origasa H, Sumitomo N, Tomobe M, Tanaka K, Minota S. Tocilizumab in systemic juvenile idiopathic arthritis in a real-world clinical setting: results from 1 year of postmarketing surveillance follow-up of 417 patients in Japan. Ann Rheum Dis. 2016;75(9):1654-60.

11. Horneff G, Schulz AC, Klotsche J, Hospach A, Minden K, Foeldvari I, Trauzeddel R, Ganser G, Weller-Heinemann F, Haas JP. Experience with etanercept, tocilizumab and interleukin-1 inhibitors in systemic onset juvenile idiopathic arthritis patients from the BIKER registry. Arthritis Res Ther. 2017;19(1):256.

12. Kimura Y, Grevich S, Beukelman T, Morgan E, Nigrovic PA, Mieszkalski K, Graham TB, Ibarra M, Ilowite N, Klein-Gitelman M, et al. Pilot study comparing the Childhood Arthritis \& Rheumatology Research Alliance (CARRA) systemic juvenile idiopathic arthritis consensus treatment plans. Pediatr Rheumatol Online J. 2017;15(1):23.

13. Bielak M, Husmann E, Weyandt N, Haas JP, Hügle B, Horneff G, Neudorf U, Lutz T, Lilienthal E, Kallinich T, et al. IL-6 blockade in systemic juvenile idiopathic arthritis - achievement of inactive disease and remission (data from the German AID-registry). Pediatr Rheumatol Online J. 2018;16(1):22.

14. Singer M, Deutschman CS, Seymour CW, Shankar-Hari M, Annane D, Bauer M, Bellomo R, Bernard GR, Chiche JD, Coopersmith CM, et al. The third international consensus definitions for Sepsis and septic shock (Sepsis-3). Jama. 2016;315(8):801-10.

15. Dong YQ, Wang W, Li J, Ma MS, Zhong LQ, Wei QJ, Song HM. Characterization of microbiota in systemic-onset juvenile idiopathic arthritis with different disease severities. World J Clin Cases. 2019;7(18):2734-45.

16. Karl JP, Margolis LM, Madslien EH, Murphy NE, Castellani JW, Gundersen Y, Hoke AV, Levangie MW, Kumar R, Chakraborty N, et al. Changes in intestinal microbiota composition and metabolism coincide with increased intestinal permeability in young adults under prolonged physiological stress. Am J Physiol Gastrointest Liver Physiol. 2017;312(6):G559-g571.

17. Jin X, Zimmers TA, Zhang Z, Pierce RH, Koniaris LG. Interleukin-6 is an important in vivo inhibitor of intestinal epithelial cell death in mice. Gut. 2010;59(2):186-96

18. Crayne $C B$, Albeituni S, Nichols KE, Cron RQ. The immunology of macrophage activation syndrome. Front Immunol. 2019;10:119.

19. Schulert GS, Grom AA. Pathogenesis of macrophage activation syndrome and potential for cytokine- directed therapies. Ann Rev Med. 2015; 66(undefined):145-59. 
20. Rosário C, Zandman-Goddard G, Meyron-Holtz EG, D'Cruz DP, Shoenfeld Y The Hyperferritinemic syndrome: macrophage activation syndrome, Still's disease, septic shock and catastrophic antiphospholipid syndrome. BMC Med. 2013;11(1):185.

21. Ravelli A, Minoia F, Davì S, Horne A, Bovis F, Pistorio A, Aricò M, Avcin T, Behrens EM, De Benedetti F, et al. 2016 Classification criteria for

macrophage activation syndrome complicating systemic juvenile idiopathic arthritis: a European league against rheumatism/American College of Rheumatology/Paediatric rheumatology international trials organisation collaborative initiative. Ann Rheumatic Dis. 2016;75(3):481-9.

22. Cimaz R. Systemic-onset juvenile idiopathic arthritis. Autoimmun Rev. 2016; 15(9):931-4.

23. Rhodes A, Evans LE, Alhazzani W, Levy MM, Antonelli M, Ferrer R, Kumar A, Sevransky JE, Sprung CL, Nunnally ME, et al. Surviving Sepsis campaign: international guidelines for Management of Sepsis and Septic Shock: 2016. Intensive Care Med. 2017;43(3):304-77.

24. Shimizu M, Nakagishi Y, Kasai K, Yamasaki Y, Miyoshi M, Takei S, Yachie A. Tocilizumab masks the clinical symptoms of systemic juvenile idiopathic arthritis-associated macrophage activation syndrome: the diagnostic significance of interleukin-18 and interleukin-6. Cytokine. 2012;58(2):287-94.

25. Machowicz R, Janka G, Wiktor-Jedrzejczak W. Similar but not the same: differential diagnosis of HLH and sepsis. Crit Rev Oncol Hematol. 2017; 114:1-12.

26. Schulert GS, Minoia F, Bohnsack J, Cron RQ, Hashad S, Kon EPI, Kostik M, Lovell D, Maritsi D, Nigrovic PA, et al. Effect of biologic therapy on clinical and laboratory features of macrophage activation syndrome associated with systemic juvenile idiopathic arthritis. Arthritis Care Res. 2018;70(3):409-19.

27. Minoia F, Davì S, Horne A, Demirkaya E, Bovis F, Li C, Lehmberg K, Weitzman S, Insalaco A, Wouters C, et al. Clinical features, treatment, and outcome of macrophage activation syndrome complicating systemic juvenile idiopathic arthritis: a multinational, multicenter study of 362 patients. Arthritis Rheumatol. 2014;66(11):3160-9.

\section{Publisher's Note}

Springer Nature remains neutral with regard to jurisdictional claims in published maps and institutional affiliations.

Ready to submit your research? Choose BMC and benefit from:

- fast, convenient online submission

- thorough peer review by experienced researchers in your field

- rapid publication on acceptance

- support for research data, including large and complex data types

- gold Open Access which fosters wider collaboration and increased citations

- maximum visibility for your research: over $100 \mathrm{M}$ website views per year

At $\mathrm{BMC}$, research is always in progress.

Learn more biomedcentral.com/submissions 